\title{
AZ ENDOGÉN FORRÁSOK SZEREPE A VIDÉK JÓ KORMÁNYZÁSÁNAK RENDSZERÉBEN ${ }^{1}$ \\ THE ROLE OF ENDOGENOUS SOURCES IN THE SYSTEM OF GOOD GOVERNANCE OF COUNTRYSIDE
}

\author{
Káposzta József \\ egyetemi docens \\ Gazdaság- és Társadalomtudományi Kar, Szent István Egyetem \\ E-mail: kaposzta.jozsef@gtk.szie.hu
}

\section{Összefoglalás}

Napjainkban olyan gazdasági változásokon megyünk át, amik alapjaiban változtatják meg a világgazdaság körülményeit, hiszen kimerültek a korábbi növekedési források, a termelötőke hozamai visszaestek, ennek megfelelően mérséklődött a beruházási kedv, mindezt tetézte a pénzügyi válság sokkoló hatása. A jelentős ipari államok gazdasági magterületein egyre súlyosabb feszültségek halmozódnak fel, részben a környezeti problémák előtérbe kerülése miatt, részben pedig a tradicionális termelési bázisok válsága következtében, amit tovább nehezített. Mindezek alapján egyre fontosabb tényezőnek tekinthető az endogén forrásokra alapozott gazdasági fejlesztések, illetve a helyi piacok fejlesztése, miszerint a helyben megtermelt jövedelmek, helyben történő felhasználása számos területen megkerülhetetlen gazdasági stratégia lett. Tanulmányomban ezt a témakört igyekszem összefüggéseiben vizsgálni és kapcsolatot találni a jó kormányzás rendszerének fejlesztéséhez.

\begin{abstract}
We are undergoing such economic changes nowadays, which fundamentally change the world economic circumstances as the previous sources for growth have been exhausted, productive capital declined and consequently the incentives for investment has reduced, furthermore it got worse with the shocking effect of financial crisis. More and more serious tension is accumulated in the economic core area of significant industrial states, partly because of the environmental problems coming to the front and partly due to the crisis of the traditional manufacturing bases, which was further hampered. On the basis of these considerations, the economic development based on endogenous sources can be considered a factor of growing importance and the development of local markets as the local usage of income produced locally has become an unavoidable economic strategy in several fields. The present paper examines this topic regarding its links and tries to find connection for the improvement of good governance.
\end{abstract}

Kulcsszavak: jó kormányzás rendszere, endogén források, vidékgazdaság

JEL besorolás: R10, R11

LCC: HD72-88

\section{Bevezetés}

Az elmúlt évtizedek növekedési periódusának hatására átalakult a szükségleti skála, megváltoztak az igények, számos új fogyasztási elem bukkant fel, amely a jóléti állam eszméjének és intézményeinek terjedésével természetes igényként jelentkezik, így az ehhez

\footnotetext{
${ }^{1}$ „A mü a KÖFOP-2.1.2-VEKOP-15-2016-00001 azonosítószámú, „A jó kormányzást megalapozó közszolgálatfejlesztés" elnevezésü kiemelt projekt keretében, a Nemzeti Közszolgálati Egyetem és a Szent István Egyetem együttmüködésével készült."
} 
szorosan kapcsolódó jó kormányzás rendszere is átalakulásban van. Mindezek kifejezésre jutnak a társadalmi, szociális akciókban (pl. környezetvédelmi mozgalmak), új életmód kezdeményezésekben (pl. new age), közösségek önmagukra találásában, az önállóság, az autonómia igények felerősödésében, ami együtt jár a regionalizmus feltámadásával. Ebben a sokváltozós viszonyrendszerben az új regionális fejlesztési stratégiát számos területen a régiókon belüli lehetőségekben, a potenciálok kiaknázásában, a saját erők megújításában és fejlesztésében látták (Káposzta-Tóth T, 2014). Az alulról induló, a regionális potenciálokra, mint endogén forrásokra épülö fejlesztésektől az várható, hogy

- a megújítások új impulzusait teremtik meg

- a természeti, a környezeti, de a térségi gazdasági adottságok és feltételek alapján, azoknak az át- és újraértékelésével a korábbiaktól eltérő programok alakuljanak ki

- integrálódnak az adott térségek szocio-kulturális hagyományai, és a lakosság részvételével a társadalmi döntésekben, cselekvésekben eleddig fel nem használt, ki nem merített források jelennek meg.

Az új területi politikák homlokterébe a térségek, a régiók adottságai, potenciáljai kerültek, amelyek a fejlesztésekhez mint belső, endogén erőforrások állnak rendelkezésre és megfelelő körülmények között aktivizálhatók. Ezen aktivitások motorja a leszakadt területek többségében a jó állam müködéséhez szükséges önkormányzati rendszer, így az összefüggések vizsgálatát elsődlegesnek tartom. A regionális potenciál értelmezésének levezetése körül a szakmai vélemények eltérőek, másként és másként nevezik meg a téma szakértői az ehhez kapcsolódó fejlesztési akciókat: „fejlesztések alulról”, „szelektív önállóság”, „autonóm régiófejlesztés"(Enright, 1998). Mindegyik közelítés egységes viszont abban, hogy az adott lokális és regionális közösségek újra tudatára ébrednek specifikus, „természetes” településitérségi adottságaiknak, termelési hagyományaiknak, a rendelkezésre álló munkaerő sajátos képzettségének, valamint a régió politikai céljait és kulturális adottságait is aktivizálva komparatív előnyökhöz juthatnak más, régiókkal szemben, így erősödik a jó kormányzás igénye (Káposzta-Tóth, 2014).

Az erőforrások megváltozása, átértékelése és szocio-ökonómiai feltételek miatt ezen adottságok lehetnek a hordozói, a megjelenítői régiók megújításának. A korábbi növekedési elméletek elhanyagolták az endogén forrásokat, hiszen a munkamegosztás jellege miatt az erőforrások (tőke, hatalom, információ) a centrumokban, a településhierarchia csúcsain koncentrálódtak, amelyek együtt jártak a térségek erős specializációjával (Káposzta, 2007, 2015). A perifériák iránt a kereslet csak a favorizált erőforrások miatt jelentkezett, így ezek a hagyományos exportágazatokhoz kötődtek, holott azokat másként hasznosítva innovatívabban, hatékonyabban járulhattak volna hozzá az adott régió fejlődéséhez, a jó kormányázás előmozdításához. Az innovációs ötletek a kommunikációs korlátok, a piaci ismeretek hiánya és az elmaradott technológia adottságai következtében is megrekedtek, nem kerültek kidolgozásra, inkább egy passzív vállalkozói magatartás kialakulását eredményezték. Végül a térségi erőforrások és képességek a régión kívüli keresleti tényezők számára „,parlagon hevertek”, közben számos funkció elcsökevényesedett, vagy éppen leépült, jobb esetben csupán konzerválódott.

Ennek megfelelően az új területfejlesztés célja szorosan kapcsolódik a jó kormányzás rendszeréhez, tehát elsősorban nem a magasan fejlett térségek adottságainak újramozgósítása, hanem a további - endogén - forrásoknak, a régión belüli potenciáloknak a hasznosítása, aktivizálása kerül az előtérbe. A fejlesztés alapproblémája szerintem az, hogy miként lehet a területi faktorokat hatékony allokációval beilleszteni az adott társadalmi termelés és tevékenységek rendszerébe úgy, hogy azok müködése optimális legyen az adott gazdasági, 
társadalmi viszonyok és feltételek között (Káposzta, 2007, 2015). Az irányzat elméleti gyökerei a generatív növekedési koncepcióban rejlenek, amiben az fogalmazódik meg, hogy a régiók autonóm fejlődési teljesítményéből, kapacitásából levezethető, sőt generálható a nagyobb területi egység növekedése, míg a komparatív előnyökre épülő regionális gazdaságfejlődés az aggregált növekedés térségekre bontott elosztásaként értelmezhető. A regionális potenciálok, mint endogén erőforrások roppant széles skálán mozognak. Kiinduló feltételezés lehet az „egyes településekben, térségekben található földrajzi, környezeti, történelmi, kulturális, társadalmi, gazdasági tényezők együttes rendszerének értelmezése és az ezen értéktartományok aktivizációját befolyásoló tényezők" (Rechnitzer, 1998) meghatározó szerepet jelenthetnek az adott területi egység modernizációs pályára állításában. Az egyes endogén tényezők közvetve vagy közvetlenül is befolyásolhatják az élet minőségét, így szoros kapcsolatban vannak a jó kormányzás rendszerével, így megtalálhatók a másik megnevezett fakorban, vagy éppen az adott potenciál-komponensek egymásra hatása révén alakul ki. A földrajzi potenciálban már meghatározódnak egy-egy térség piaci lehetőségei, vagy kapcsolatai. Ezzel a faktorral jellemezhetjük a közlekedési, a kommunikációs infrastruktúrát, annak viszonylatait és korlátait (Káposzta-Tóth, 2014). A térség munkaerő-potenciálja már megjelenik a népesség összetételében, de behatárolja a szocio-kulturális adottságokat is, és kihat a tőkeállományra, annak aktivitására. A településállományban rejlő adottságok fellelhetők ugyanúgy a tőke potenciálban, de az infrastrukturális rendszerekben is, és visszahatnak a munkaeröre, a humán dimenziókra. Látható, hogy ezen endogén tényezők önmagukban is értelmezhetők, de kölcsönös meghatározottságaik révén összefüggnek egymással, sőt bizonyos társadalmi, gazdasági körülmények között megindíthatnak aktivizációs folyamatokat, kiválthatják vagy magukban hordozhatják az adott tér megújításának lehetőségét. A területi potenciálok összekapcsolódhatnak, így közöttük kialakulhatnak egymásra épülések, olyan szövevények, amelyek újabb aktivizációs tereket nyithatnak meg és más, további endogén forrásokat alakíthatnak ki.

A területi potenciál tehát egy-egy térség endogén forrásainak összessége. Ezek az adottságok megmaradtak, elrejtőztek vagy parlagon hevertek a korábbi gazdasági kapcsolatokban és fejlesztési modellekben. Ezek összekapcsolása, rendszerük értelmezése és a fejlesztésekbe történő bevonása meggyőződésem, hogy a jó kormányzás feladata. A megváltozott körülmények között természeten megfelelő exogén hatásokra aktivizálhatók, hordozói lehetnek a térségek megújításának. Egymás közötti kapcsolataik, átfedéseik és hálózataik új dimenziókat kínálhatnak a regionális fejlesztésben, ha a dinamikus kölcsönhatások exogén tényezőkkel erősödnek meg, azaz a szinergiák révén a térségi megújítás új fejlödési pályát alakíthat ki.

\section{Az endogén források szerepe a helyi gazdaság és a közigazgatás fejlesztésében}

A helyi gazdaság, a gazdaságnak azt a legalsó müködési szintjét jelenti, ahol a termelés és a fogyasztás közvetlenül összekapcsolódik. A gazdaságnak ez a típusa egyszerre tradicionális, mert a világ számos pontján máig létezik és újszerü, mert egyre inkább újra felfedezik, mint a fogyasztói társadalom alternatíváját, illetve a gazdasági nehézségekkel küzdő térségek gazdasági fejlesztésének egyik eszközét (Porter, 1998, 2000). A történelemben a lokális gazdaságot alapvetően a helyi viszonyok határozták meg, nem volt jellemző az áruk nagy távolságra való szállítása, a termelés, a feldolgozás és a fogyasztás térbeli elkülönülése. A gazdaság helyi viszonyainak újraszervezésében alkalmazható a vállalkozásösztönzés, a vállalkozások közötti együttmüködés, a lakosság vásárlói tudatosságának erősítése, a közvetlen termelői-fogyasztói kapcsolatok elősegítése, továbbá közösségszervezési akciók, annak tudatosítására, hogy az emberek maguk is sokat tehetnek saját környezetük gazdasági talpra állításáért. Kifejezett cél, hogy az adott gazdasági tevékenység eredményei helyben hasznosuljanak, akár mint megvásárolható termék, elérhető szolgáltatás, vagy mint munkahely 
és jövedelem, amiben jelentős szerep jut az önkormányzati, közigazgatási rendszernek (Káposzta-Tóth T, 2014). Vagyis a helyi gazdaságfejlesztés nem egyszerüen helyi, hanem helyi érdekü gazdaságfejlesztés, melyben a jó kormányzás kapcsolatrendszere fontos tényező. A helyi piacot kívánja a helyi vállalkozások és gazdasági tevékenységek ösztönzésével támogatni, a helyi közösség érdekében. Célja tehát nem kizárólagosan gazdasági, hanem meghatározóan közösségi és társadalmi: a helyi lakosság életminőségének javítása, nem pedig a bármi áron történő profitmaximalizálás. Ezért - szemléleti és módszertani megközelítésére egyaránt utalva - helyi közösségi gazdaságfejlesztésnek is nevezhetjük. Ideális esetben a helyi gazdaságfejlesztő tevékenység helyi kezdeményezésként valósul meg, de kezdetben külső beavatkozás, szakértelem szükségessé válhat. Ez annak függvénye, hogy az adott térség rendelkezik-e rátermett és elhivatott szakemberekkel, akik „motorjai” lehetnek a folyamat beindításának, szervezésének, illetve rendelkezésre áll-e elegendő bizalmi töke, ami a helyi közösség aktivizálásához elengedhetetlen (Porter, 1998, 2000). Ez a helyi piac „helyi mezőgazdasági termelőket, kézmüves mestereket, kisiparosokat, kiskereskedőket" igényelt, így biztosította a foglalkoztatást. A helyi gazdaság fellendítésének, fejlesztésének tehát napjainkban is kiemelkedő jelentősége van. Számos előny - köztük környezetvédelmi, gazdasági, társadalmi szempontok - indokolják a versenyképes helyi gazdaság megteremtését, amiben meggyőződésem, hogy a jó kormányzás rendszere, és szerepe megkerülhetetlen.

Mai gazdasági rendszerünket tekintve a helyi gazdaság és a helyi gazdaságfejlesztés a gazdaságnak azt a legalsó müködési szintjét jelenti, ahol a termelés és a fogyasztás közvetlenül összekapcsolódik, tehát a lokális térben. Ez a típusú helyi gazdaság egyszerre tradicionális, mert a világ számos pontján máig létezik, és újszerü, mert újra felfedezik, mint a fogyasztói társadalom alternatíváját. Egészen a modern korig a gazdaságot alapvetően a helyi viszonyok határozták meg. A mainál lényegesen kevésbé volt jellemző az áruk nagy távolságra való szállítása, a termelés, a feldolgozás és a fogyasztás térbeli elkülönülése. Az egyének megélhetése fokozott mértékben épített az önellátásra (Lengyel, 2010). Vidéken az emberek élelmiszer-szükségletük jelentős részét maguk állították elö. Ez a helyi piac helyi mezőgazdasági termelőket, kézmüves mestereket, kisiparosokat, kereskedőket igényelt, így biztosította a foglalkoztatást. Ezzel szemben ma helyben is többnyire külsö, globális meghatározottság érvényesül. A ,helyi piac” a gazdaság globalizálódása miatt egyre kevesebb vállalkozást tart el. A helyi termelök, vállalkozók termékeiket nagyrészt településükön, térségükön kívül értékesítik, a helyi piacon jellemzően a máshonnan - gyakran igen távolról szállított áruk forognak (Goda-Tóth, 2013). Ennek egyszerre oka és következménye, hogy sok, ún. „hátrányos helyzetü”, leszakadó településen szinte eltünt a helyi gazdaság, csak néhány vállalkozásra, boltra korlátozódik, miközben sok ember munkajövedelem nélkül él, ennek következtében fogyasztása alacsony. Mindezen összefüggések is jól mutatják a helyi közigazgatás rendszerszervező feladatát. Mindezek lapján a helyi gazdaságfejlesztésben kitüntetett szerepet kap az együttmüködés. Egyik legfontosabb jellemzője, hogy keretében a helyi szereplők (gazdaság és társadalom) együttmüködnek a helyi gazdasági tevékenységek ösztönzése érdekében, olyan akciókat hajtanak végre, amelyek a helyi adottságokhoz illeszkednek, a helyi erőforrásokra építenek, meglévő és az új helyzetekből következő új helyi keresletek kielégítésére törekszenek (Káposzta-Tóth, 2014). A vállalkozói szféra, az önkormányzatok és a helyi közösség közös gondolkodása és közös akciói segíthetik elö, hogy a speciális helyi adottságokra építve a közösség képes legyen a változó helyi és külső körülmények között megőrizni saját értékeit és lehetőségeit. Ez egyben alkalmazkodóképességének javulását is jelenti. Ugyanakkor ez minden esetben egy kezdeményező (,pro-aktív”) alkalmazkodás, mely során a helyi értékek, hagyományok, erőforrások megőrzése és fenntartható használata, valamint a helyi lakosság igényeinek, 
szükségleteinek kielégítése úgy történik, hogy az hosszú távon összhangban van a környezeti, társadalmi és gazdasági fenntarthatóság követelményeivel.

Az együttmüködés térségi dimenzióban is megfogalmazható: Miért szükséges a globális világban a likális gazdaság fejlesztése? A lokális piacok a globalizáció negatív következményeinek ellensúlyozására, kivédésére alkalmasak a helyi ellátó rendszerek, melyek a termelő és a fogyasztó minél közvetlenebb és rövidebb értékesítési-fogyasztási kapcsolatára épülnek. A Magyarországon egyre több helyen alulról szerveződő helyi piac, illetve helyi ellátást célzó kezdeményezések azt mutatják, hogy megfelelő szervezéssel biztonságossá tehető az áruk értékesítése, kiszámíthatóvá téve a termelést, az ellátást és az e tevékenységekből élő családok megélhetését. A vidéki térben talán a legnagyobb hangsúllyal a helyi élelmiszertermékek íz- és zamatanyagokban gazdag, jó minőségü termékei kerülnek elötérbe, melyek keresettek mind belföldön, mind külföldön, mégis az import áruk egyre nagyobb térnyerését, a hazai termékek visszaszorulását tapasztaljuk. Ezen tényezök is egyre inkább szerepet kapnak a vidékbiztonság erösödésében. A helyi, illetve közvetlen értékesítés, a közvetlen termelöi-fogyasztói kapcsolatok, a kistermelői, helyi feldolgozás megteremtése még kevéssé jellemző Magyarországon, így az önkormányzatok szervezői munkáját fontosnak tartom, hiszen a decentralizált élelmiszergazdaságnak számos előnye van: a helyben megtermelt élelmiszer (zöldség, gyümölcs) frissebb (a betakarítás/szedés a fiziológiai érés állapotában történik), kevesebb feldolgozást és tartósítást igényel, így tápanyagtartalmát jobban megőrzi és egészségesebb. A változatosabb, polikultúrás helyi élelmiszertermelés nagyobb türőképességgel rendelkezik a környezeti stressz hatásokkal szemben, valamint kevésbé fenyeget a nagyobb mértékü szennyeződések bekövetkezése. A helyi specialitások nem csupán az élelmiszer- és étkezési monokultúra káros hatásait ellensúlyozva egészségügyi szempontokból előnyösek, hanem gazdaságélénkítő hatásuk is jelentős (Káposzta-Tóth T, 2014).

Adódik a kérdés: Gazdaságilag van-e életképes helyi gazdaság a jelenlegi globálissal szemben? A válasz nyilván nagymértékben függ a gazdasági környezettől (támogatások, szabályozások), de a teljes életciklus elemzések eredményei sok esetben alátámasztják az alternatív gazdasági, termelési rendszerek előnyei. A helyi gazdaság támogatása, a munkahelyek megőrzése és újak teremtése révén a vidékfejlesztés fontos eszköze, emellett a lakosságmegtartó képességét is jelentősen segítheti (Swinburn-Goga-Murphy, 2004). A legjelentősebb közösségi gazdasági előny a lokális multiplikátor hatás, amely elsősorban a hátrányos helyzetü térségek fejlödését segíti azáltal, hogy a megtermelt jövedelem nagy része a helyi közösségekben marad, és újabb jövedelemtermelést indukál, ezzel segíti a helyi jó kormányzás célrendszerének megvalósulását. A helyi gazdaság fejlesztése a szociális kapcsolatokat és a szolidaritást is erősíti. A fenntartható lokális gazdaság fö alkotóeleme a helyi, tradicionális gazdálkodási ismeretek (a fenntarthatóság mintáinak) megőrzése és az aktuális helyzetben, legjobban hasznosíthatók gyakorlati alkalmazása a széles körü közösségi erőforrásokra (természeti, gazdasági, kulturális, politikai, társadalmi, egyéni) alapozva. A közösségek erősítése az életképes helyi gazdaság kialakításának, újraszervezésének kulcsa, ugyanis a gyenge közösségek kiszolgáltatott társadalom kialakulását okozzák, amelyre a fokozott társadalmi igazságtalanságok és szociális-gazdasági feszültségek, konfliktusok a jellemzőek, amelyek egy körfolyamat eredményeként gátolják a társadalmi töke növekedését (Todaro-Smith, 2006), így nehezíti a jó kormányzás feladatinak ellátását. Összességében a helyi gazdaságfejlesztésnek számos pozitív hatása van, amelyek területfejlesztési és vidékfejlesztési jelentőséggel bírnak:

- helyi vállalkozói tevékenységet generál

- munkahelymegörző- és teremtő szerepe van

- mozgósítja a helyi közösséget, bővíti a helyi együttmüködési hálót 
- a helyi erőforrások fenntartható használatához vezet

- erősíti a helyi identitást és lokálpatriotizmust

- a település népesség-megtartó erejét növeli, élhetőségét javítja

- megújítja a város-vidék kapcsolatokat.

\section{Helyi termékek gazdasági hasznossága}

A helyi gazdaságfejlesztés lokalitásának elönye mellett érdemes egy kis kitérőt tennünk a helyi termékek irányába. Napjainkban a helyi gazdaságfejlesztés talán legdivatosabb és legismertebb eszköze a helyi termékek elöállítása és fejlesztése, valamint ehhez kapcsolódóan, de esetünkben kissé külön, önálló eszközcsoportként kezelve a helyi termékek értékesítésének és promóciójának tevékenységei (Kajner, 2009). A helyi termékek elöállításának ösztönzése elsősorban a térség lakosságának ellátását szolgálja, de a beavatkozások az értékesíthető termékek fejlesztését is célozhatják (Lengyel-Deák, 2002). Ehhez szükséges a helyi adottságok, hagyományok figyelembevétele, a helyi értékek és készségek feltárása, értékkataszter, értékleltár készítése, melyek elkészítésében, folyamatos bővítésében rendkívül nagy szerep hárul a jó kormányzás inzézményrendszerére. Szükséges lehet a helyi értékek, potenciálok fejlesztése és védelme (például natúrpark keretein belül), valamint a helyi húzó ágazatok azonosítása (pl. piackutatás, SWOT elemzés). A helyi termékek fejlesztése során kiemelkedő jelentőségü az értékláncok alapján történő szerveződés elősegítése, amely a promóció és értékesítés elősegítése mellett kiterjed a feldolgozás, raktározás, szállítás tevékenységeire is (Tóth, 2018).

A beszállítói és felvásárlói hálózatok, együttműködések elősegítése kulcstényezője a folyamatnak. Számos további intézkedés lehetséges a helyi termékek értékesítésének támogatására, a helyi piacok, piaci infrastruktúra, piaci szolgáltatások fejlesztésétől kezdődően a felvásárlói körök kialakításán keresztül helyi termékek arculati fejlesztéséig, a helyi termékek mintaboltjának (helyben vagy közeli városokban, esetleg az interneten) kialakításáig, vagy helyi termék polcok felállításáig az áruházakban (Lengyel, 2010). Ide sorolható továbbá a marketing eszközök széles körü alkalmazása, a helyi termékbemutatók falunapokon, fesztiválokon, vásárokban, továbbá a látogatható mintagazdaságok kialakítása. Utóbbiak előnye, hogy a helyi termékek megvásárlásának ösztönzésén túl hozzájárulnak a helyi értékek, gazdálkodási hagyományok megőrzéséhez, a helyi kötődés, identitás erősítéséhez, és a turisztikai potenciált is javíthatják (Káposzta-Tóth T, 2014). A vidékies térségekben a direkt és online marketing lehetőségei kiemelkedő jelentőséggel bírnak. A vidéki és elmaradott területeken az önellátástól és az őstermeléstől az értéklánc magasabb szintjei felé való fokozatos elmozdulás elősegítése, a tájegységenként diverzifikált agrárgazdaság kialakítása elősegítheti a minőségi, piacképes helyi termékek előállítását, helyi márkák kialakítását. A szállítási költségek és a szállítás környezeti terheinek minimalizálása céljából ösztönzendő a helyi piac ellátása.

Mindezek alapján fontos tényezőnek gondolom a vidék gazdaságágban a helyi piacok kialakulását, a helyi értékesítésre irányuló kezdeményezések megvalósulását, az ezeket elindító helyi együttmüködéseket, a helyi értékesítést magában foglaló helyi gazdaságfejlesztési stratégiák megfogalmazását. A kialakuló gazdaságfejlesztési stratégiák megvalósulásához szükséges a helyi termelési kapacitás, a helyi igények, értékesítési lehetőségek felmérése, a termelési és értékesítési folyamatok összekapcsolása (szövetkezetek, éttermek, közétkeztetés, önkormányzatok együttmüködései), a termelés tervezhetösége. Továbbá fontosnak tartom a helyi piacok, vásárok, pavilonos értékesítés lehetőségének biztosítása mellett, a helyi termék védjegyrendszerek bevezetését, a helyi termékekkel kapcsolatos szemléletformálást. Úgy gondolom, hogy szervezett, nyomon követhetö, kistérségi szintre épülö, országos termelési, 
feldolgozási, logisztikai, értékesítési stratégia, rendszer kiépítése fejlődést adhat egy adott terület gazdaságának, ezzel is jelentősen segítve a jó kormányzás stratégiai feladatrendszerét. Véleményem szerint ösztönözni szükséges a helyi termékekre, termelésre alapozódó kistermelői, kisléptékü feldolgozó kapacitások létesítését, fejlesztését, összekapcsolva a családi gazdaságok erősítésével és a helyi értékesítés fejlesztésével. Cél a hozzáadott érték növelése és a bevételek helyben, arányos mértékben a gazdálkodóknál tartása, ezzel is fejlesztve a lokáli életteret.

\section{Összefoglalás}

Mindezek alapján jól látható, hogy a vidék gazdasági fejlesztése nem nélkülözheti a lokális gazdaság szereplőinek együttmüködését. Ezen szereplők gazdasági, oktatási, szolgáltatási rendszere mellett a helyi önkormányzati rendszer, a jó kormányzáshoz tartozó egyéb közigazgatási szervezetek közös együttműködésével, az EU és a hazai támogatási források ésszerü és okszerü stratégiai tervezésével kidolgozható egy olyan fejlesztési modell, ami a fenntartható gazdaság minden feladatát képes lesz ellátni. Ebben a helyi, meghatározó társadalmi szereplö, a helyi hősök a vállalkozások és az önkormányzatok szoros együttmüködésére lesz szükség.

\section{Köszönetnyilvánítás}

„A mű a KÖFOP-2.1.2-VEKOP-15-2016-00001 azonosítószámú, „A jó kormányzást megalapozó közszolgálat-fejlesztés" elnevezésü kiemelt projekt keretében, a Nemzeti Közszolgálati Egyetem és a Szent István Egyetem együttmüködésével készült.”

\section{Felhasznált irodalom}

1. Egri Zoltán-Köszegi Irén Rita (2018): A gazdasági-társadalmi (komplex) térszerkezet kelet-közép-európai képe. TERÜLETI STATISZTIKA 58:(1) pp. 27-56. (2018)

2. Egri Zoltán (2017): Települési egészségegyenlőtlenségek a gazdasági fejlettség triadikus felbontása alapján. STUDIA MUNDI - ECONOMICA 4:(3) pp. 32-44. (2017)

3. Enright M. J. (1998): Regional Clusters and Furm Strategy. In Chandler et al. (szerk.): The Dynamic Firm: The Role of Technology, Strategy, Organization, and Regions. Oxford University Press, New York, 315-342

4. Goda P.-Tóth T. (2013): Pókháló- entrópia, mint új rendszervizsgálati megközelítés a területi elemzésekben. TERÜLETI STATISZTIKA 53:(2) pp. 169-189. (2013)

5. Kajner P. (2009): Helyi termelés, helyi fogyasztás, helyi termékek egészségesen! SZÖVET.

6. Káposzta J. szerk. (2007): Regionális gazdaságtan. Tankönyv. DE Kiadó Debrecen, 2007. ISBN 978-963-9732-79-7. 300 p.

7. Káposzta, J.-Nagy, A.-Nagy, H. (2013): Tourism infrastructure index and the distribution of development funds in statistical regions of Hungary Agrarnyi Vestnik Urala / Agrarian Bulletin of the Urals 2013:(12) pp. 80-83. (2013)

8. Káposzta, J.-Nagy, A.- Nagy, H. (2014): Efficiency of Hungarian regions in using the development funds for touristic purposes. Regionalnaja Ekonomika: Jug Rossii / Regional Economy: The South of Russia 4:(6)pp. 33-39. (2014)

9. Káposzta J.-Tóth T. (2014): Regionális és vidékfejlesztési ismeretek. 168 p. Gödöllö: Szent István Egyetemi Kiadó, 2014. ISBN:978-963-269-402-3

10. Káposzta J. (2015): A vidékgazdaság fejlesztési kérdései a XXI. században In: Bíró A Zoltán, Gyetvai Árpád, Magyar Ferenc (szerk.) Kreatív fiatalok - innovatív vidék: 
Sikeres helyi fejlesztési gyakorlatok a Székelyföldön. 188 p. Csíkszereda: Státus Kiadó, 2015. pp. 13-22. (Új utakon a tehetséggondozás VI.) ISBN 978-606-661-0407

11. Kozári József (2003): A mezőgazdasági szaktanácsadás finanszírozása a nyugateurópai országokban. GAZDÁLKODÁS 47:(5) pp. 67-71. (2003)

12. Kozári József-Tóth Krisztina (2011): The role of extension in the technical improvement of agricultural enterprises. NAUKOVIJ VISZNYIK 168:(3) pp. 34-39. (2011)

13. Kulcsár László-Kozári József (1998): A vidékfejlesztés új stratégiája Magyarországon. GAZDÁLKODÁS 42:(4) pp. 11-21. (1998)

14. Lengyel I. (2010): Regionális gazdaságfejlesztés. Versenyképesség, klaszterek és alulról szerveződő stratégiák. Akadémiai Kiadó, Budapest.

15. Lengyel I.-Deák Sz. (2002): Klaszter: a helyi gazdaságfejlesztés egyik sikeres eszköze. In Buzás, N.-Lengyel, I. (szerk.): Ipari parkok fejlődési lehetőségei: regionális gazdaságfejlesztés, innovációs folyamatok és klaszterek. SZTE GTK, JATEPress, Szeged. 125-153.o.

16. Nagy, H.- Káposzta, J. (2010): Social and regional aspects of the structural and Cohesion Funds in the new EU member states between 2007-2013. In: Peter Bielik (szerk.): Economics, Social Policy and Citizenship in the European Union - Evidence of V4 Countries and Perspectives for Ukraine. 258 p. Nitra: Slovak University of Agriculture, Faculty of European Studies and Regional Development, 2010. pp. 148167. ISBN: 978-80-552-0448-2

17. Oláh I. - Ritter K.- Tóth T. (2013): The role of local communities in the disadvantaged rural areas In: Szendrö Katalin, Soós Mihály (szerk.) Proceedings of the 4th International Conference of Economic Sciences. 595 p. Kaposvár: Kaposvár University, 2013. pp. 547-553. (ISBN: 978-963-9821-62-0)

18. Porter M. J. (1998): Clusters and the New Economics of Competition. Harvard Business Review, Nov-Dec. 77-90. o. (magyarul: Regionális üzletági központok - a verseny új közgazdaságtana. HARVARD BUSINESS manager, 1999/4. 6-19. o.)

19. Porter M. J. (2000): Location, Competition, and Economic Development: Local Clusters in a Global Economy. Economic Development Quaterly, 1, 15-34. o.

20. Rechnitzer J. (1998): Területi stratégiák. Dialóg Campus, Budapest-Pécs.

21. Swinburn, G.-Goga, S.-Murphy, F. (2004): A helyi gazdaságfejlesztés kézikönyve.

22. Területfejlesztési füzetek (2), a helyi gazdaságfejlesztés. NFM, NGM VÁTI Budapest, 2010. ISBN: 978-963-7380-21-1

23. Todaro, M. P.-Smith S. C. (2006): Economic Development, Addison Wesley, Boston.

24. Tóth T. (2018): Gazdaságfejlesztési lehetőségek a jól müködő településeken. STUDIA MUNDI - ECONOMICA 5:(1) pp. 59-67. (2018)

25. Tóth, T. (2008): Applying Methods and Processes Used in Regional Planning and Analysis to Regional, Rural and Small Area Development In: Peter Bielik, Bogdan Klepacki, Sergii Kvasha (szerk.) AGRICULTURAL MARKET AND TRADE: Evidence and perspektive of V4 Region and its Neighbour - Ukraine. 157 p. Warsaw: Editorial House Wies Jutra, 2008. pp. 105-119. (ISBN:83-89-503-62-x)

26. Molnár Cs.-Tóth G.-Kincses Á. (2009): A fürdőfejlesztések hatásai KeletMagyarországon. TERÜLETI STATISZTIKA, 11: pp. 597-614. (2009)

27. Remenyik Bulcsú-Molnár Csilla-Tóth Géza-Sóvári Katalin (2013): A tóturizmus helyzete Magyarországon. AGORA: A BGF KVIFK KULTURÁLIS TUDOMÁNYOS FOLYÓIRATA, 2013. (10) pp. 90-105. 